\title{
[En]gendering the norms of customary inheritance in Botswana and South Africa
}

\author{
Rosalie Kingwill
}

\begin{abstract}
The article responds to the article by Weinberg in this issue. She traces the trajectory of court hearings concerning the contested inheritance of land in Botswana, which, after several prior judgements eventually resulted in a positive outcome for the woman litigants. I acknowledge the author's key argument, which concerns the impact of power relations on the construction of customary law and the reproduction of knowledge in the courts. Certain versions of "custom" were promoted and others stilled to the disadvantage of women. I argue that the normative patterns of landholding are indeed gendered, but do not result in a binary structure of men and women. "Gender" should be disaggregated to take into account a range of status criteria within and across the categories of male and female in order to understand the differential impact of social relations on the outcomes of property struggles. The normative lines of property transmission frequently follow a logic of "family property" that allows for qualifying women to rights of property. Family property has vastly different social and legal consequences to private, individualised property rights. The corollary is that it is misleading to speak of the processes of succession to rights of access to, and control of customary property in terms of one-to-one "inheritance" of land. The concept of "living law" inadequately reflects these social dynamics.
\end{abstract}

\section{Introduction}

This article responds to the article "Pushing the boundaries of customary law jurisprudence in Botswana: social science and the law in the case of Ramantele vs. Mmusi" (in this issue). The author analyses some of the implications of a long drawn-out intrafamilial legal tussle over inheritance of land in Botswana, contested in the courts between 2007 and 2013. The case was heard in five different courts (the first three being customary courts) culminating in a ruling from the highest court in the land, the Botswana Court of Appeal, which ruled in favour of Edith Mmusi and her sisters.

That article is mainly concerned with the construction and reproduction of knowledge in court discourses, with a focus on the effect of power imbalances on the constitution of knowledge, particularly gendered constructions of customary norms governing the transmission of land. The particular issue at stake is how the courts interpret customary law rules and processes with regard to inheritance of land, and how these interpretations 
are shaped by those who have access to power. The rules tend to be articulated by interests that are able to control the reproduction of rules, persistently associated with masculinity and seniority. By extension, the rules tend to be lifted out of their current social contexts and frozen in a preconceived and imagined past that once served the interests of the colonial state. The Mmusi case demonstrates that though the old interpretations continue to be invoked in post-colonial contexts, they are being increasingly and convincingly contested.

The author argues that the very processes by which courts arrived at decisions contributed to the reproduction of anachronistic norms, since evidence was required to fit into a framework of preconceived rules. Indeed, the entire conception of customary law during the colonial era was founded on a search for "immemorial rules" at the expense of the conceptual development of a body of law. Customary law itself was built on a discriminatory and subordinate foundation that did not treat it as "law" - in the sense of a system of evolving law - but on the premise of supplying facts to fit a rule-bound conception of customary law. This construction was no accident, but fitted the needs of the colonial political structure that required the subservience of customary law to common law. One may infer that male black power holders were complicit in entrenching a structure of rules based on a patriarchal conception of black society in their attempts to shore up their waning political authority (Chanock 1991, 73).

The judgement discussed in the Mmusi article is presented as breaking new ground in this regard. The author reviews the approaches that were taken in the hearings that culminated in in the final judgement in the Court of Appeal. In the latter, the judges paid attention to arguments presented by the lawyers representing the respondents, Edith Mmusi and her four siblings. Their legal team used evidence from various sources, including social science research, and employed concepts of a flexible "living law" approach to customary law to argue for a fair outcome that would at the same time promote gender equality. The article sees the Mmusi case as offering hope that a new approach to customary law is dawning with the courts willing to engage in a wider range of sources, and to use evidence to debate the meaning of customary law, rather than merely support or deny this or that "rule."

There is an underlying assumption that the struggle for justice in Mmusi centred on gender alone, and that the Edith Mmusi and her sisters were victorious as women in a more universal struggle against patriarchal norms affecting the outcome of inheritance in an African context.

In response to the article I acknowledge the strength of the key argument concerning the impact of power relations on the reproduction of knowledge in the courts, and how certain versions of "custom" were promoted and others stilled, the latter frequently intersecting with gendered and generational hierarchies, with women and youth least empowered to have their voices heard. 
While accepting that one of the key fault-lines of customary law bisects along malefemale lines, I argue that the processes that shape familial relationships reveal a more complex set of social relations. The Mmusi article, by its very parameters, does not approach the problems of inheritance from a social relational or ethnographic perspective, though the author acknowledges the importance of these dimensions for more nuanced analysis. Ethnographic research suggests that relationships involving property (in this case specifically land) tend to follow kinship, clanship and frequently lineage ties calculated according to patterns of descent (a 2014, Peters 1997; Mills and Wilson 1952, 47; Nhlapo 2000, 139-142; Berge et al 2014, 61-69). Peters argues that the basis of almost all African landholding systems, regardless of whether the descent system is patrilineal or matrilineal, is that of clan or lineage or kinship.

Certainly there are other principles of social organization and various practices that also inflect landholding claims and rights such as alliance, friendship, various types of clientage, etc. But the bedrock was and in most places still is kinship - and in most places that means lineal relations. ${ }^{1}$

Berry $(1989 \mathrm{~b}, 45,50)$ argues that people continue to invest in social relationships and proliferating social networks in spite of changes in the political economy, and these continue to mediate access to land:

Rights in land continue to be associated with membership in descent groups, etc., even in areas where transactions in land rights were highly commercialised. Even outright state appropriation has often failed to transform patterns of land access and use. [...] Several recent analyses have argued that understanding processes of rural differentiation in Africa is not a matter of deciding whether socio-economic cleavages are predicated on kinship ties or class interests, but rather one of elucidating their interactions.

The emphasis on kinship in the argument that follows should not be interpreted to mean that kinship is determinative:

Today, social theorists are more inclined to see kinship or descent or marriage as sets of discursive and action strategies, less determinants of social life as frameworks for it, less causes of behaviour as arenas for interpretation, negotiation and contestation. (Peters, 1997, 129)

My own research led to similar conclusions. I go further, however, to argue that the normative patterns that result from, and shape, kinship-based social organisation are fundamentally gendered, but that do not result in a binary structure of men and women (Kingwill 2014a, 227-255). The lines of differentiation are more nuanced. The concept of gender should be disaggregated to take into account different status and class criteria within and across the categories of male and female. While these intersect with a range of other socio-cultural criteria and economic processes, the combined effect on the outcome of property struggles suggests that analyses of gender relationships ought to move beyond a 
narrow focus on women as a single category, to embrace a more holistic conception of property relations.

As hinted at by the author herself, the "living law" prism of customary law, though influential in the positive outcome of the Mmusi case, offers little analytic clarity on how social channels of access to land and resources group and regroup along lines of power, interest and gender. The strength of the living law prism is that it reflects transforming social realities rather than archaic normative principles, but this view alone does not uncover the competing interests that lie beneath the surface of contemporary struggles over property. Indeed, the opposing parties in the Mmusi case both hitched the concept of living law to their respective arguments.

My response attempts to fill some of the gaps that are revealed by methodological weaknesses in research and legal argument that reduce gendered struggles over property to a simple dichotomy between men and women, individually or collectively. In the case of inheritance of land, I argue that the problem is exacerbated by poor cross-cultural translation of the term "inheritance" to the passage of landed property. The term translates relatively unambiguously when referring to the transmission of property by a predecessor to identified individuals, and particularly with respect to moveables. When it comes to inheritance of immovable property, the term translates uneasily crossculturally, since in many societies land is not considered an individual asset for disposal or transmission to women or men.

The trajectory of inheritance in any society is usually associated with the cultural interpretation of kin and is thus not a term that can be applied universally to any situation of property transmission without reference to structuring effects of kinship relationships. Inheritance is conditioned by how, culturally, people define to whom they consider themselves to be related and in what way.

In much of Africa, processes of transmission of land do not result in transference of property rights to individuals, male or female, but follow lines of succession across generations where related kin are considered eligible for rights of access to the land (Kingwill 2014a, 78-84, 267-278). The emphasis is thus not on individual inheritance. Land is regarded as a family asset, and is not considered individually transmissible or marketable. In such circumstances, the term "inheritance" is misleading without qualification.

The Mmusi case touches on this aspect, since it was not Edith Mmusi alone who gained the rights of inheritance after the Appeal Court judgement, but she and all her siblings, who happened to be female. The mechanics and dynamics of why a set of siblings, rather than an individual (Edith Mmusi) acquired the legitimate rights to the property in question are not elaborated in the various court judgements. In the final judgement, the emphasis on living norms may have obscured the importance of complex dimensions 
that lurk behind the processes that shape evolving interpretations of social identity and property relations.

\section{Main lines of argument in the Mmusi article}

In grappling with gendered power struggles over property, the author considers how customary law more broadly is treated in courts. She discusses, for example, competing interpretations of customary law; what is accepted as evidence; and the scope of customary law in relation to common-law. The substance and status of customary law was as much in the dock as the contestants.

The thread along which the argument moves is how legal knowledge, which is itself an outcome of power relations, is created in courts and what the effect is on customary jurisprudence. Indeed, questioning the epistemological basis of law-making is an underlying theme of the article. The article grapples with the problematic ways in which the courts have treated customary law in the colonial and post-colonial period, and engages the debate about what qualifies as law. The author asserts that customary law has not been treated as a "system of law" as much as a supplier of rules according to which cases are adjudicated on the basis of facts supplying evidence on a case-by-case basis. A case-by-case, rule-based approach, the argument implies, constrains the scope for systematic development of customary law, as once-off judgements do not contribute to the growth of a body of law that can draw on precedent and contribute to the conceptual development of customary law qua law. These qualities set customary law apart from common law. The latter develops as a constantly evolving body of law that draws from precedent, with societal change progressively imbricated in ongoing interpretational modifications.

According to the article, customary law has been victim to regimes of power and hegemony over time that have either mauled or moulded it to fit in with prevailing ideologies. Even after independence, many of the legal regimes that had been established during the colonial era were incorporated into post-colonial jurisprudence, if not "wholesale". Official customary law has not had the chance to evolve into an African common law in the same way as the imported common law has evolved over time. Instead, it is stunted by its inability to absorb social change, being subjected to the scrutiny of timeless rules rather than precedent and context. Official customary law came to reflect the implausible notion of unchanging tradition, having been constituted in the political interface between colonial and traditional authority, mediated by power brokers who had an interest in entrenching rules that bolstered their respective interests.

In contrast to this trajectory of customary law, the author evaluates the Mmusi case in terms of its potential to set a new legal benchmark for gender and property rights in its attempts to engage in more inclusive processes to adjudicate these rights. These aspects make the case worthy of reflection more broadly. Indeed, the potential to break new legal ground was not lost on legal activists, who provided assistance in various ways, and a leading 
advocate in South Africa was briefed to represent the applicants in the final stage of the case, namely the hearing by the Supreme Court of Appeal. He was briefed by a law firm in Botswana, which worked in collaboration with the Southern African Litigation Unit.

The lawyers identified the importance of drawing on a range of sources of evidence, including social science research, to provide a countervailing narrative to the conventional evidence presented in court. The author reveals that she herself was involved in the review of social science literature. The legal team contacted the research unit at the then Centre for Law and Society ${ }^{2}$ at the University of Cape Town, where she was employed as a researcher, to provide an overview of social science literature on women's inheritance, specifically searching for examples of the family home passing from parents to their daughters rather than to sons. It was this involvement that prompted an interest in evaluating both the case itself and the uses and advantages of drawing from social science. In other words, the author is interested in exploring the potential of scholarly ethnographic and sociological sources to influence the otherwise hegemonic discourse in the courts that tend to draw on the evidence presented by the more powerful voices as if they are indisputable facts.

The article raises questions about how both lawyers and activists challenge the hegemonic discourses that affect customary jurisprudence, which are so frequently intersected by gendered power distinctions. The less powerful voices that are frequently blocked in cases involving customary law - as a result of the case-by-case rather than systemic approach - are those of women, and hence the importance of legal outcomes of litigation for gender equality. The main point of the article is that customary law jurisprudence was advanced in the Mmusi case in so far as the judges were willing to engage with living law and social science research, resulting in a fair judgement that advanced women's rights in property by accepting that inheritance does not as a matter of rule follow male lines only. Critically, the author suggests that the case engaged with the nature of customary law by questioning substantive issues of custom rather than merely the application of highly prejudicial rules.

In her reflections as a member of the research team the author reveals a conundrum. Part of the legal strategy was to put the concept of "living law" firmly on the table in the court deliberations in order to strengthen the case for female inheritance, in this case the applicants Edith Mmusi and her sisters. Lawyers and activists, notably in South Africa (Claassens 2013; Claassens and Mnisi 2009; Claassens and Mnisi 2012), have conceived of the idea of "living law" or "living customary law" to challenge the hold of the "official" versions of customary law that have carried the constraints and biases of colonial power structures, many of which have paradoxically been reproduced in the post-colonial period. The opposing side, however, also argued the case on the basis of "living law". The author therefore has to confront the analytical weakness of living law as a lever for progressive jurisprudence. The different versions of living law presented at the hearing raise a 
dilemma for advocates of living law. How does one convince an audience of the plausibility of "living law" where it can be used by both sides to support a different direction?

In arguing her case for a credible version of living customary law, the author identifies flexibility as an important distinguishing characteristic. It is this quality of flexibility that is sacrificed on the altar of conformity to a notion of customary law as a source of "immemorial rules" frozen in time and space, rather than a source that reflects the socially nested and adaptive features said to characterise customary practices. One could add that customary law arrives at more accommodating outcomes through processes of negotiation in contrast to the western system of judicial process that responds to contestation in an adversarial manner. Seen in this light, an essential ingredient of living customary law could be seen to embody the actual processes of negotiation itself (Berry 1993, 148; Cousins 2008; cf critique by Peters 2006).

The author acknowledges that an uncritical concept of living law may obscure the hidden power dynamics that lie behind all processes of property disputation and may itself unwittingly reproduce distortions. She refers to the analysis by Cousins that a processual theory of law may be of more analytic value than "living law" to uncover the social dynamics of power relationships that lie behind social transactions. Cousins argues that Moore's processual theory of legal change and continuity offers a more precise analytic tool than a theory of living law, which obfuscates "the underlying social dynamics that produce rules, practices and emergent social realities" (Cousins 2013, 73).

The author points out that Cousins' critique is a warning to academics, activists, lawyers and litigants to take local social dynamics seriously when they put forward the idea of living law in the courtroom. Indeed she suggests that all sources of evidence, including academic scholarship, should be subject to rigorous analysis and critical scrutiny, since all sources are potentially political materials that advance some interests at the expense of others. These competing analytical discourses complicate the terrain of activism in relation to law reform, particularly in so far as strategic concerns may override a more durable analysis of change.

It is well to remind ourselves that both "living law" and "processual" interpretations of custom and law are "historiographical". The appearance of these concepts in legal and anthropological scholarship coincides with particular historical and political contexts where major changes in the political economy posed questions about the very notion of customary law and heightened Africanist scholars' sensitivity to what the author calls the “"ghettoisation' of customary law." Its vulnerability to colonial interests inspired a need to historically contextualise the way it was and is represented. Representing law as "process" and identifying the prevalence of non-state legal orders in terms of the "living law" are conceptual devices that draw attention to the power imbalances, as well as the distinctions, between imported and indigenous normative orders, and what passes for law. 
In summary, the article raises issues that are wide in scope, presenting a challenge for a deeply penetrating analysis of the effect of changing social relationships on jurisprudence. The author is burdened with having to discuss the minutiae of a particular case with all its fact and detail, as well as the scholarship, the jurisprudence and the dilemmas of activist involvement in litigation. She acknowledges that a simple analysis of female inheritance falls short of reflecting the more complex layering of social relationships.

My response attempts to broaden the analysis by discussing the significance of social relations and affiliation for the transmission of land drawing from ethnographic research in one particular context in South Africa. The importance of this line of reasoning lies in the distinctive patterns of land transmission that arise from kinship and other significant social relations which the law inadequately reflects, and even evades. By law I mean statutory law, common law and customary law with respect to property, succession and inheritance. A more rigorous analysis of transmission practices that reside largely outside the ambit of formal law (and even what is becoming accepted in courts as "living law") could serve to clarify the gendered tensions that come into play in the contestations that arise around property. Such clarifications could help to fill the gaps in the evolving laws of succession that do not adequately take into account the social dynamics of African land ownership and its transmission.

\section{The family-property nexus}

The main lines of my argument concern the continuing influence of African familial social relationships on the management and distribution of rights in property. I refer to empirical evidence from two case studies in the Eastern Cape, South Africa, to draw out broader, more general lessons for approaching the tangled legal problems that arise when inheritance of land is contested on the basis of gender. The research sites are Rabula, a rural site in the former Ciskei "homeland", and Fingo Village, an urban township in Grahamstown. In the cases discussed, the land is owned in freehold title. The research findings reveal that African freeholders tend to customise title to fit with family norms, rather than with legal prescripts (Kingwill 2008, 2014a). The presence of historic title, while fairly rare in Africa, has methodological value in that the legal heritability of title sheds light on family transmission practices without the complicating factors of chiefly control. On customary lands where no title exists, the processes of transmission are embedded in more complicated layers of space and authority, even where traditional authorities have limited practical involvement in the passage of family land.

The freehold case studies reveal that in most cases families have continued to own their land parcels for generations, which can be substantiated by documentation. A great many are descended from the first grantees who were issued title in the mid-nineteenth century. They describe the land as "family property". By this they mean that the rights are held by, and transmitted through, the family as a whole, and not individuals. This adaptation runs contrary to Western-law constructs of title, which, as in South African property law, requires precise identification of individuals that hold and acquire surveyed land parcels at a given time, i.e. it is socially, spatially and temporally bounded. The law requires that the 
title is held by living persons or entities who are identified and registered in their individual capacity; and whose heirs (in the case of intestate inheritance) are individually identifiable according to the relevant succession laws.

In the research sites, families have continued to regulate their relationship to the land in terms of customary concepts of kinship and descent. The property-owning family nexus comprises male and female kin (past, present and future) related through the male line of descent. Termed "lineages" in social science theory (in this case "patrilineages"), no such exact term exists in their language, isiXhosa. People refer to lineage land as "family property" and the genealogical links in terms of various concepts such as: a family tree (umnombo); forebears (imilibo); "our people" (abantu bakowethu) or "father's people" (abantu bakulotata). The absence of a specific word is not surprising, since lineages were not corporate institutions nor property holding entities in the past (Hammond-Tooke 1984). Rather, identification with a lineage provided a social framework within which arrangements around marriage, residence, property distribution, rituals, celebrations, anniversaries, etc., took shape. Lineages interlocked with larger and more significant units, viz. clans for which there is a specific word, isiduko, with which every Xhosa-speaking person identifies, as clans were, and still are, important in regulating rules of exogamy and establishing social identity (Preston-Whyte 1937, 187; 197). The introduction of land title has had the effect of solidifying formerly more fluid lineal relationships into semi-corporate property holding structures, which are thought of by their members to exist in perpetuity (cf. Fortes 1953, 11, 15). 3

Lineage affiliation mobilises a "line" of members whose claims of access to family resources are based on eligibility as kin. Members and successors are thus not quantified, but embrace the "dead, the living and those not yet born." Rules defining eligibility to property and authority generally define categories of potential heirs to property or office, rather than designating individuals (cf. Berry 1989b, 42). This conception of a line of eligible successors may be contrasted with the western-law notion of the elementary or nuclear family, where particular individuals can be identified at any given time. In the latter case, ascendants and descendants are traced through both parents (bilaterally) and related members can be named and quantified at each generational cycle. The distribution of rights to landed property through inheritance can thus be confined to particular identified individuals.

Where family property is concerned, concepts of property and family are mutually reinforcing. Title creates a close link between the property itself and the family nexus. Title is a means by which the very fabric of the family is bolstered and strengthened, since the land underpins familial social relationships and "belonging" and vice versa. In this way, title paradoxically strengthens lineage identity. The distribution of social entitlements across networks of related kin constrains the development of individual autonomy regarding property rights in land. This outcome is quite the opposite of what title is intended to bring about according to the logic of property ownership in a modern market 
economy. The logic of family property militates against accumulation of property whether through purchase, allocation or inheritance - by members in their individual capacities.

The trajectory outlined is not conflict free, and does result in tensions and contestations. Family members, both male and female, have contradictory impulses to break away from the traditional constraints of family-held land by asserting - or attempting to assert

- greater levels of individual autonomy. Some men paradoxically do this by appealing to "traditional" masculine roles and duties, such as Mmusi's nephew in the Mmusi case. In these cases, men attempt to combine their customary positions of authority with individual control over family property, thus undermining the customary rights of female kin to family property. These contests are thus frequently fought along the lines of gender.

Oral narratives in the research sites in the Eastern Cape, disclose some of the details of how family members maintain rights of access to family property across successive generations. Rights of access are not absolute, however. Status and affiliation, which guarantee rights in principle, are mediated by a range of "achieved" social criteria such as the degree of investment in the property, participation in family affairs and contribution to familial welfare and property maintenance (cf. Berry 1989b, 42).

A large number of the present-day freehold owners in the two research sites trace their ownership through genealogical connections to an earlier titleholder, in many cases the first titleholder, who is regarded as the founder of their lineage. This conception is in keeping with the classical lineage definition of a line of successors descended from a single apical ancestor. Respondents' articulation of "family property" is framed in terms of its temporal reach to antecedents, the present generation and future generations, and is seen as the embodiment of an interconnecting set of relationships that are part of a moral economy.

Generational succession can seldom be traced precisely according to title deed records, since family members do not routinely register transfers. Registration frequently skips generations. Insofar as deeds are occasionally updated, the processes of adjudication and conveyancing are not generally initiated by the title holders themselves, as required by law, but are undertaken by state-appointed commissioners 4 whose roles have been created precisely to address the widespread phenomenon of non-registration of transfers. Sporadic documentation backed up by oral evidence confirmed that many of the present generation of rights holders can be traced back to the first owners whose names appear on the original title deeds.

Seth Ndawo, when asked who owned the family property in Rabula, answered by way of a rough family tree, saying that the title "belongs to" the following family members: his [deceased] grandfather (tat'omkhulu); his [deceased] grandfather's brother; his 
[deceased] grandfather's three sons and a daughter; the offspring of his great-uncle; and now the present generation, male and female. The "first man", whom the family think of as ukhokho (great-grandfather), was the original grantee, Ndawo. "We don't have a new title. The only title we are having is in Ndawo's name." 5 The present generation still conceive of the title in terms of the progenitor of the title. His explanation reveals the indissoluble link between the property and the lineage that was spawned by the forebear who acquired the property.

Seth Ndawo maintained that government officials were exhorting families to update their titles, saying a commissioner 6 would be appointed, as the "titles must be transferred to a living person ...." He was sceptical of the proposal since “... the title does not belong to him [the name in the title], it is a family affair ... Papers are important governmentally, but people here know that it's a family affair."7 Underlining this idea, another interviewee said: "Registering is just a formality. Underneath the formality, the family works out its $\mathrm{n}$ arrangements. The land will never get sold. That's the convention. There is no way one of them could sell" 8 His cousin-brother agreed. "We don't do it according to the law, we just do it alone"9 (Kingwill 2014a 196, 216; Kingwill 2014b, 241).

The property-holding structure is held together by the concept of a family custodian, a representative selected to manage, maintain and defend the family property and act on behalf of the entire family and in the interests of all its members. This person is validated by family consent and not by title deed. Xhosa terminology struggles to find new terms for these concepts. The idea of "keeper", "caretaker", even "housekeeper", meaning someone who "looks after" the property, has resulted in a widely used Xhosa term, umgcini ekhaya (keeper of the home), adapted from the verb ugcina, "to look after." Educated people prefer to use the term imeli (representative) and some think the "keeper" analogy implies servility. No particular expression has replaced customary concepts, but in English "responsible person" is the most common.

Family members with rights in the family property regard themselves as one family, umzi omnye, even though under present-day circumstances they are simultaneously members of smaller family units that are spatially stretched across various urban and rural landscapes (Kingwill 2014a, 176, 344, 347). This understanding is in keeping with the jural concept of a property-holding lineage structure as "a single legal personality", called by the Ashanti "one person" (Fortes 1953, 25). Many of these family segments own their own properties elsewhere, but this does not jeopardise their stake in the family property, providing members conform to the basic principles of affiliation. Families are socially differentiated, incorporating both richer and poorer members. Indeed one of the rationales of family property is to provide shelter for those in need.

"Family property helps to keep the family together", according to Linda Sindiso Mnyemeni of Fingo Village. In words resonant across Fingo Village, she maintained: 
I will leave this property to my children because this is their home, bought by their fathers who passed away. They were born here and grew up here .... We call it family property because sometimes someone is disabled or unemployed. They can come back to that home. If a son or daughter [falls on hard times] you will take them in, even my grandchildren .... ${ }^{10}$

Siphiwo Baninzi's story relating to the family property in Fingo Village was similar:

[I]n terms of our life, we have what is called the extended family. You may have somebody that we do not know who is related to this home. Maybe he went to the mines and worked there for years, or for ages, then when he comes back if we sell this place he will ... have nowhere to stay ... . So that thing is of assistance .... If my father for example by chance has another child that we do not know, and as the time goes, we pick up that he does have this child, then it means, if he or she has nowhere to go, this is also his home or her home where he can be accommodated here. If he's got to be buried, then this property, we would use it for making preparations. ... So that is the value of keeping the home. Because, if you don't keep it, then it means such people would have nowhere to go, nowhere to be buried, and so on. ${ }^{11}$

Both expositions emphasise the importance of family property in taking care of potentially indigent or disabled family members. The criterion of "need" accentuates the imperative of keeping familial social networks alive, durable and resilient.

The norms that perpetuate the concept of family property clash with the formal legal principles of freehold tenure as conceived in the country's system of registration, which encourages proprietary control by named individuals. Here, rights are calculated as precise apportionments of property mathematically subtractable from a quantifiable whole.

Legal protections of family obligations under formal title historically were abandoned as these came to be seen as a burden on the development of land as a commodity with the onset of commercial and capitalist relations of production. ${ }^{12}$ Legal historians have shown that the South African judiciary opted for a Romanesque interpretation of exclusive proprietary rights vested in individuals (Chanock, 2001, 376-377; van der Walt \& Kleyn 1989, 248-9; van der Walt 1999). The circle of family membership came to be defined ever more narrowly (Rautenbach 2008) to concentrate property in the hands of the conjugal couple and their children (Kingwill 2014a, 327-329). In the distant past, western law accommodated extended family obligations, but even there the rights were expressed in terms of quantifiable rights or shares ${ }^{13}$ defined in terms of the conjugal pair and their children and grandchildren, who trace their relationships bilaterally through both parents. 
As demonstrated, this conception of divisible property contrasts with the rights of access by qualifying kin to family property, which is seen as indivisible. The twin demands of preserving the indivisible common estate and maintaining inter-generational kinship relationships militate against individual autonomy and proprietary rights. The very mechanism of unilineal succession as a basis for rights of access to land contradicts the concept of individual heirs. Succession practices that perpetuate the family line through consanguinity, rather than conjugality, keep the lines of access open to all members categorised as kin.

One example from the rural site may serve to show how families identify their members. This branch (a sub-lineage) of the Ndawo family, identifies its members as the descendants of Jack, who is regarded as the founder of their branch of the family. The family refer to Jack as utat'omkhulu (grandfather), and through him the family members trace their rights to the property. According to family custom, the property devolves to each new generation descended from Jack, calculated through the male line only. All agnatically related ${ }^{14}$ family members, male and female, have rights to the property under the management of an identified custodian. Arable land is informally subdivided among the children, male and female. Women (sisters and wives) are allocated fields if domiciled within the patrilocal residence. These are use rights only. ${ }^{15}$ In theory the individual fields (which together constitute the surveyed land parcel) revert to the common pool when individual users die, but in practice they are often specifically allocated to particular named members, a phenomenon that is sometimes referred to as "inheritance", though it is not so in the legal sense.

The convention in rural Rabula is to place the responsibility for the management of the family property in an identified individual as custodian, which until more recently was almost always a male, but not necessarily the eldest male, as in the past. The emphasis nowadays is on personal attributes of responsibility, which is a logical extension of the customary role of head of the family in the past, who was responsible for the welfare of the entire family. In modern times, the requirement of "responsibility" includes the capacity to fulfil this function, and thus the requirement that custodians should be men is falling away. In Jack's family, the custodian at the time of the interviews was Caleb, grandson of Jack. As he was very sickly, his sister Albertina was beginning to take over the control of the property. She is actively involved in managing the land and intended to assume the role of custodian from her brother after his death, an indication of changing gendered norms in Rabula. Critically, however, she never relinquished her family name, Ndawo, and has passed it on to her three children. Retaining the family name is a crucial device by which female kin retain their access to family property, as it removes the threat of women introducing new lines of descent through partners or husbands.

The family conceptualises its claims to ownership in terms of genealogical ties that link all agnatically related kin to the property. Ownership is seen to vest in the entire family unit, 
and not in the individuals. This approach stands in stark contrast to the official view that seeks to register identified individual "owners" or "heirs" on the title deeds.

The Ndawo case illustrates how women claim rights as daughters or sisters within the parameters of patrilineal descent. This remains an important means by which modern women claim rights, and is a logical extension of women's access to land in pre-colonial times. ${ }^{16}$ The official version of customary law under colonial rule misinterpreted rights of access as a male prerogative. Extrapolating from numerous other stories in Rabula, the retention of the family name by a woman of the lineage secures her patrilineal identity. As a wife of another lineage-holder she would not be entitled to claim rights to Ndawo property, but as a sister she is eligible. Her eligibility rests on her status as a daughter of the landholding patrilineage, reinforced by the family name and residence. In interviews about the family property, the father of her children was never mentioned, suggesting that her children's rights to family property are secured through her patrilineal identity and family name. ${ }^{17}$ By retaining the family name she has simultaneously secured her own as well as her children's access in future.

In Rabula it is still rare for women (as sisters) to be accorded the status of both family head and custodian of the family property but, as the above case illustrates, there are indications of change. This does not mean that women do not as a rule command authority over family property in Rabula. Their authority is, however, mediated through men and the family name. As sisters of the patrilineage they have full rights of access to the land,

and must be consulted on all matters with a bearing on the family property. ${ }^{18}$ Married sisters may not, however, derive rights of access unless they do so as separated, divorced or single women. This logic extends to wives married to the male members of the patrilineage, who have far more constrained property rights to the land than the sisters of her husband who are regarded as direct descendants. Wives are thus excluded from the family kinship nexus and regarded as full members of their own lineage. This does not, however, mean they have no authority. They have access to use rights to the land and make decisions about the arable land, and receive and control moveable property. They are respected as mothers, have authority over children and make decisions affecting the family. They are, of course, emotionally connected with the family and are usually regarded as the head of the household if their husbands have died. The authority they do not have, however, is to make decisions that involve changes to the status of family property, and they may under no circumstances make decisions that involve its disposition to anyone outside of the lineage, and that includes their own kin.

In the story above, Albertina Ndawo, in her capacity as daughter and sister, maintained her rights to family property by retaining her family (lineage) name and passing it on to her children. Her position of authority as recognised custodian is still somewhat novel in Rabula, but indicative of a growing trend, which is already firmly established in Fingo Village. Here the feminisation of this role is advancing apace, as it becomes increasingly 
common for women to be chosen as the custodians, since they tend to be viewed as being more "responsible" than men. Whereas previously the role of custodian was prescribed by birth status, nowadays status can be both achieved as well as ascribed. The key modern principle is less that of the gender of the custodian, than that of ensuring that the property is retained by and for the family, given the threat of dispossession posed by market forces and individualisation of claims to the property through registration or inheritance, which can lead to arbitrary sales. A key mechanism to achieve this is to reproduce and maintain the lineage connections to the land to underpin the principle of family ownership.

Land could be said to vest in the abstract notion of the family (lineage) acting as trustee for the family members, represented by the family name. Kinship ties actually serve to perpetuate the family name through unilineal succession. In one case in Fingo Village, the family property was threatened by potential disposition out of the family name by the wife of an errant member of the family. Here the pressure to retain the family estate within the lineage called for the strict application of norms that define inclusion and exclusion. One of these is the strict taboo against wives claiming family property as her personal share in the conjugal property. The fear is that if a wife secures individual rights in the family property, she may transmit the land to her own kin or a new husband, thus ceding the property to a different landowning lineage. In this case, the property was claimed by the wife of the family's deceased kinsman who, according to the family, took it over illegitimately and purported to own it as an individual. His widow, as predicted by the family, subsequently attempted to will the property to her own kin. Her husband's family waged a bitter and prolonged struggle to recover the property. It was in fact the female agnates, straddling several generations, who spearheaded this campaign. They challenged the wife's will and contested the distribution of property by the Master of the Supreme Court who is charged with administering deceased estates in South Africa. Here the contest was fanned by female kin opposing the claims of a wife, an inter-gendered struggle. ${ }^{19}$

In short, the narratives all relate in one way or another to the principle that individuals relate to the property through their kinship networks, and do not inherit the land in their individual capacities, nor have the right to dispose of the land unilaterally. The normative order does not mean that people do not attempt to do just that. The focus on kinship should not be interpreted to mean that norms determine outcomes, but rather that kinship provides a conceptual structure within which contests are argued and struggles waged. Kinship is conceived in the sense that Peters expressed the concept as "less a determining structure of groups than as a way of representing relations" (1997, 128; see also Kingwill 2014a, 78-80).

\section{Translating patterns of succession and inheritance}

The patterns of succession described above stand in stark contrast to the formal conscripts of ownership and inheritance. The social-organisational principles that define the passage of immovable property cast doubts on whether the formal concept of "inheritance", which 
conventionally defines rights in property transferred to particular individuals, is, in its present form, an adequate expression of the processes that characterise the devolution of land that follows succession calculated from descent.

I have argued above that immovable property vests in a family-property nexus where individual property rights are derived from the property rights of the descent group. The exercise of those rights is constrained by the tension between the individual and the landowning group. The property owning structure could be conceived of as separable from its individual members, not unlike a private property-owning trust. There is no legal concept for this configuration of property since there is no accommodation in South African law (common law or customary law) for descent-based family property arrangements in spite of the prevalence of these forms in customary land-holding contexts, however variable in detail they may be, and whether or not there is a formal title or record.

Colonial officials wholly misrepresented this configuration in South Africa by codifying the law of customary succession to immovable property in terms of male primogeniture. ${ }^{20}$ This distortion played into the hands of male powerholders. In practice, historically, the eldest adult male succeeded by virtue of status and seniority to a position of prestige and responsibility (authority), but certainly not to heirship of immovable property or land (Kingwill 2014a, 86). There was, however, a concept of individual heirship to some categories of moveables. Where the senior adult male was the heir and property distributor, his position was known as indlalifa.

The concepts of inheritance and ownership are integrally related and interlocking. How property is transmitted cannot be divorced from how it is owned. Since the law does not recognise descent-based family ownership (with or without title), there is no law of succession or inheritance that matches this category of ownership. In the case of title, the choice of whether to apply common law or customary law rules to inheritance was decided according to whether marriage was by custom or civil rites. In reality, neither matched the conditions on the ground. It is hardly surprising that in practice decisions regarding succession were, and still are, arrived at following local normative conventions outside of the law (Kingwill 2014a, 156-255).

In the landmark Bhe judgement in $2005^{21}$ the majority judgement came to the conclusion that customary succession practices were out of sync with modern practices. The old discredited official customary law of succession (with its emphasis on male primogeniture) was rightly repudiated. Failing legislative developments, all intestate succession is, as a consequence of the judgement, to be decided in terms of the common law approach to statutory succession. ${ }^{22}$ The judgement conflated male primogeniture with customary succession as a whole, painting all of the customary law of succession with the same brush. Stripped of an opportunity to match the law with practice, people continue to negotiate and contest solutions both within and between families. In the event of 
complicated estates, they may seek assistance from officials or magistrates in finding negotiated solutions, failing which they turn to customary and state courts. It is in these very processes of negotiation and contestation that adjustments, reinterpretations of custom, and circumventions of norms are made, transforming in the process many gendered stereotypes.

The normative patterns that come into play in matters of access to land could be likened to a social "eco-system" that follows a conceptual and directional logic that sustains its continued reproduction. 23 Social eco-systems are not uniform or static, but constantly adapt to new socio-economic environments and challenges. People constantly manoeuvre and strategise around circumstances as they arise in order to maintain or enhance powers or rights of access and their transmission over time. Their strategies are conditioned by distinctive socio-spatial contingencies that affect concepts of property, such as: the symbolic and ritual representations of belonging; the social unit that holds the land; the social organisation of the unit; how social relationships are channelled; how the spatial parameters of the land influence future possibilities; marriage status and residence patterns and

how these influence decision-making; the economic logic of property, i.e. its value as either a capital asset or a social asset; and how labour is organised and investments in production or social networks are made, etc. While structural principles do not "determine" social organisation and behaviour as implied in some older anthropological theories, Pauline Peters points out that such organising principles (norms, ideas, representations) are not without effect (Peters 1997, 127).

Okoth-Ogendo $(2008,101)$ argued that it is "misleading in the extreme to try to analyse tenure of land and resources in terms of the conceptual categories of Anglo-European property law"; and called for a more rigorous understanding of African property relations. It is, he said, a "juridical fallacy that indigenous law conferred no property in land" and built a theory of African land tenure as embodying "property relations" (2008, 96). He argued that the search for "ownership" - in the sense used in modern western thought should be replaced with the concept of the "allocation of power" over land. This idea involves a switch from conceptualising property in terms of the relationship between an owner and a property object or "thing", to the relationship between persons with respect toproperty.

He challenged ideas that property relations involve only exclusive property or that authority over land is ordained only from higher authorities (e.g. chiefs). Rather, control is exercised "through the permanent members of the particular unit of production involved" (Okoth-Ogendo 1989, 11). He argued that access is based on recognised social affiliation to a social unit, and authority (control) involves the supervision of specific functions at different levels of social organisation $(2008,101)$. 
He redefined African tenure in terms of "access rights" that correspond with powers of "control" (governance), shifting in relation to each other in time and space according to changing socio-economic dynamics. "In these tenure regimes there is no coincidence of access and control, and property does not involve the vesting of the full complement of power over land that is possible (that is private property)" (quoted in Cousins 2008, 129). The "powers" Okoth-Ogendo identifies as central to property relations are rooted in the "social process through which society deals with how that power should be vested in particular members thereof and the mechanisms through which that process is controlled."

[It] would appear to be self-evident that the existence of a power, per se, implies some form of property and that it is not essential to or even prudent in all human relationships that a coincidence of power and exclusivity of control in any individual or group of individuals in respect of all contexts, things or objects should exist. (Okoth-Ogendo 1989, 8) 24

His theory of African property relations built on Paul Bohannan's earlier concepts of "man-man" and "man-land" relationships. Bohannan maintained that all cultures conceptualise their relationships to land in three dimensions: (a) they have a concept of land, such as a representational "map" of the country in which they live; (b) a mode of correlating humans with their physical universe, i.e. the relationship between humans and things ("man-thing" relationships); and (c) a social system with a spatial dimension, i.e. their social organisation and how it relates to space ("man-man" relationships) (Bohannan 1963, 104). He analysed various societies in Africa and showed how these variables shift relationally and proportionately according to different ecological, social, economic and political circumstances (1963, 104-110). He concluded that in the main, the "man-thing" relationships that tend to characterise western systems of thought about property are less of an organisational principle in African contexts than "man-man" relationships which emphasise the social-relational aspects of land holding. He called for a "folk" view of land tenure that transcends the dominance of western-law property concepts, terminology and models of land tenure (see too Pierce 2013, 156-7).

In this article I argue that a key site of cross-cultural mis-translation is how social units, such as the family, are defined for purposes of succession and inheritance. As alluded to above, the statutory law of succession in South Africa defines the "family" extremely narrowly to include only the elementary or nuclear family based on the conjugal unit (two parents/one parent and children) as eligible for succession (Rautenbach 2008). In response to increasing pressures for reform of laws that discriminated against white women, the Succession Act of 1934 included "spouses" in the category of "successors", by providing for spouses to inherit intestate property, largely to acknowledge the property rights of widows. Thus succession law began to follow the trend in the west, which, despite South Africa's "legal mosaic" of Roman-Dutch and English legal principles, moved in the general direction of emphasising the conjugal family, thus narrowing the claims of members of the extended family to a small circle of eligible heirs associated with the nuclear family based on conjugal relationships (Rautenbach 2008, 7). 
The progressive narrowing of the definition of the family circle has followed the increasing commercialisation and commodification of land, with concomitant concentration of property in the hands of particular recognised individuals associated with the immediate family. This atomised model allows for accumulation by a small group of identifiable individuals in the family, since the land is regarded as an asset base that grows in value and provides security of capital and tenure for the individual owners and their heirs.

In contexts where land owners or holders do not see their land as a commodity held as a fungible asset to be exchanged according to market values, arguably relevant in large parts of Africa, various mechanisms combine to retain the land as a social asset and prevent disposition by or to an individual, such as those described in the cases above. What these landholders refer to as "the family", which is really the set of agnatically related members of the patrilineage, is not a corporate entity so much as a form of trusteeship, the life of which is independent of its individually recognised members (see n. 3). For practical purposes, as we saw above, a "custodian" is nominated to maintain and manage the land, and generally steer its use and passage in the interests of all its members.

This model of landholding, comprising eligible kin with access rights rather than individual owners with proprietary powers, stands in stark contrast to the one-on-one direct property relationships envisaged in western-law notions of registered ownership by individuals. Sara Berry characterised the African model as a combination of a "bundle of rights" and a "bundle of rights holders." "The way in which a particular resource was managed depended on relations amongst rights-holders as well as on the jural content of the rights they held" (Berry 1993, 41). The well-known metaphor of a "bundle of rights" demonstrates that rights in a property can be separated into many strands comprising different sets of relationships to the property. The idea emerged in western (mainly English) property discourses to challenge the Romanesque notion of property as a fusion of exclusive powers vested in a single owner. The "bundle of rights" nevertheless refers to the subject-object relationships, and not the subject-subject relationships, and is hence not an entirely satisfactory representation of customary rights.

The notion of a "bundle of rights holders", by way of contrast, brings to the fore the critically important component of social relations that often form the basis claims to rights or resource access (Berry 1993, 127). As discussed above, rather than forming a fixed group, rights holders can be understood as constituting a category of eligible rights holders whose claims are based on "social identity" (Berry 1989b, 42; see also Ribot and Peluso 2003, 164-5; 170-1). Eligible members are thus categorised in a way that is markedly different from the western-law model of designating individuals, legitimated by way of registration in the Deeds Registry. Here, in contrast to the mechanism of claiming rights by way of social identity linked to descent group ideology, claims to rights to immovable property are made in terms of legal standards, which are defined in terms of 
quantifiable sets of numerical formulae and named legal personae that are calculated according to relationships based on the conjugal couple. In many African contexts, however, as Roitman $(2005,90)$ put it: “... the question of property is not so much unspeakable as conditional, depending on which relationships are involved" - and thus does not readily yield to "quantification and nomination." This model characterises much of the land tenure relationships in Africa despite the deepening impact of market forces, and despite the increasing evidence of market-like exchanges of land (Colin \& Woodhouse 2010; Rutsch Howard Consortium 2004; Berry 1989b, 45).

Ribot and Peluso (2003) go even further, and argue for the importance of distinguishing between "bundles of rights" that define property relations, and "bundles of powers", which comprise a wide range of access mechanisms that may be short of property rights. This line of argument positions a range of rights and powers in relation to a range of resources, which takes the emphasis off one-on-one property relationships and dissolves the binary of individual and communal tenure. The authors theorise about, and document, a wide range of qualifying mechanisms that grant various rights and powers of access. These fluctuate in response to changes in the political economy, legal frameworks, the material basis of natural resources, etc.

"Social identity" is identified by Ribot and Peluso as one of many important structural and relational mechanisms that qualify people's powers or rights of access to resources (164-5, 170-1). This formulation is helpful in situating social identity (which includes the "family-property" nexus discussed in this article) as an important source of rights and powers in land in African contexts, but not the only one.

Okoth-Ogendo observed that some of the core dimensions of African property relations are extremely durable and resistant to change. Normative frameworks of access may not necessarily undergo visible change even in the face of market penetration and new agrarian relations that manifest in more "compact, usually family-based, units." He uses the example of the transition from nomadic pastoralism to various forms of agriculture to show that, though the control (governance) structures change fairly fundamentally, the powers of access remain relatively undisturbed. He concludes that "certain categories of access power are extremely resilient to change" (Okoth-Ogendo 1989, 14).

Berry provides a rich tapestry of evidence of continued reliance on social relations to channel new patterns of access to, and control over resources in Africa. Processes of access to, and control of resources proliferate in an exponential and dynamic manner. Changes build upon each other to create conditions of ongoing transformation of relationships, with recursive patterns of maintaining and reproducing social networks, including, but not restricted to, kinship relationships (Berry 1989b, 43-52, 1993, 127, 148-9). "In an African context it is clear that "people's ability to exercise claims to land remains closely linked to membership in social networks and participation in both formal and informal political processes" (Berry 1993, 104). 
She argues that land was one of many resources that underwent changes with regard to access and control under indirect colonial rule, the contestation over which leads to uncertainty or tension within and across local social units such as kin or descent groups. The processes of grappling with these challenges in turn affect the strategies of resource use. She weaves the interrelated processes of access to land, labour and capital into her theories of changing land tenure relationships, showing that land is not always the constraint on production. Her broader focus on changing resource allocation underlines the importance of Okoth-Ogendo's definition of land tenure systems as comprising the allocation of power and its exercise, rather than simply being about "sets of rules concerning rights in land" (1989a, 2).

Her argument (1989a, 2) supports the main lines of Okoth-Ogendo's theory, that in addition to its material value in production, land is:

1. A focus for the definition and exercise of rights of access which extend to other productive resources.

2. A social asset as a means by which people maintain their local social kinship affiliations and social identities.

She stresses that identities may be both "ascribed" or "achieved", and do not evolve unaltered from their "traditional" forms which tend to stress birth status only. People become members of multiple social groups, and land, labour and capital combine differently in different processes of production and exchange (1993, 166). Land nevertheless remains a fulcrum on which various aspects of social affiliation, culturally constructed identities and group membership turn, becoming resources in themselves $(1993,160)$.

Dependence on social relationships, however, tends to act as a brake on individual accumulation, the development of productive resources and investment in longer-term economic strategies of enlarging productive capacity (1989b 51; 1993, 133, 180). Even in circumstances of accumulation, group structures seldom develop into closed corporate structures of control and management, but their boundaries remain fluid and contested, militating against the growth of a landed class (1993, 180, 200). She observes that individualisation of labour has been far more pronounced a trend than individualisation of land relations.

These arguments demonstrate that the distribution of power among family members is deeply influenced by the nodes of power around which pre-existing social networks run, including the gendered dimensions thereof (Kingwill 2014a, 46-49; 61-63; Berry 1989b, 41-55; cf. Moore 1978, 13). Numerous scholars have attempted to explain the purported "resilience" of core norms that gravitate around social relationships and property concerns. Berry concludes that that, while colonial rule changed the mechanisms of access to land, it did not dissolve African social and familial relationships, and might even in 
some respects have strengthened reliance on traditional social networks, in altered form (Berry 1989b, 41-55), which the cases studies discussed above certainly bear out.

Moore also observed that the "patterned aspects" of social norms (or "culture") may well be resilient to change, though not determinatively so (Moore 1978, 49). For Moore the concept of change was not a shift from the "traditional" to the "modern", but a tension between countervailing processes of change and continuity. She distinguishes two kinds of processes. Processes of regularisation are those which produce rules, organisations, customs and symbols, rituals and categories to make them durable, to fix them, and introduce an element of predictability. Situational adjustment, on the other hand, is a response to immediate situations, exploiting the "indeterminacies" of situations, and providing the opportunity for reinventing and reinterpreting the rules or relationships. These are countervailing processes that involve both regularities that perpetuate social conditions on the one hand, and adjustments to particular sets of circumstances on the other (Moore 1978, 39, 47-48, 50; and see Moore 1987, 735).

Why, in the face of change, are some regularities more actively maintained and reproduced than others? Moore ventured an explanation:

One possible reason ... may be that in pre-industrial circumstances the maintenance of relationships of social exchange between social units depends heavily on the existence of replicated units with like normative orders. This may act as a brake on significant normative changes within individual subunits since innovations might cut off important relationships. The commitment to maintaining connections among units might account for some of the putative stability of customary law (Moore 1978, 13) (emphasis added).

Despite the flexibility, adaptability, contestation and negotiation emphasised by the new influential literature on Africa exemplified by Berry (1993), Lund (2002, 1-10) and Cousins (2008), Peters shows in her detailed ethnographic work that the various elements involved are not randomly flung together, that there is "a certain systematicity in social practices and ideology" (Peters 1997, 138; 2002, 45-47). She cautions against over-correction towards "negotiability", with its sometimes unintended over-emphasis on flexibility, contingency and indeterminacy, which misleadingly suggest that social relations in modern African society are marked by open-endedness. Investment in social relationships should not be conflated with endlessly fluid property relationships. Under circumstances of change, such as commercialisation and new avenues of wealth, customary social relations may mask processes of concentration and accumulation, and some claims to property do "stick" (Peters 1997). Berry similarly observes that ongoing investment in proliferating and fluid social institutions may generate contradictory economic returns by constraining the development of productive capacity, but may at the same time mask processes of privatisation and concentration, as well as social differentiation within as well as across kin groups (1989b, 51; 1993, 132-3, 155-8). Individual members of landholding groups have differential statuses and their relationships are mediated by cultural concepts of affiliation and socially and culturally constructed identities, such as 
gender or generational status. These relationships also involve the means of exploitation of labour within family groups.

Using matrilineal patterns of social organisation as an example, Peters posits a theory of regularity that supports the transformative potential of custom without entrenching the idea of closed systems:

Multiple dimensions add up to something typifiable; negotiability and contestation take place in culturally particular modes. One does not need to posit a closed or total system but neither a totally open-ended one. People experience and channel change through preexisting ideas, ways and practices. The sets of ideas and practices constituting and enacting matrilineal organization, therefore, present a particular definition of reality for people ... While not immune to modification and change, that particular definition constitutes a different kind of reality from non-matrilineally organized groups. (Peters 1997, 138)

The "typifiability" she describes can be extended to other forms of social organisation, such as the patrilineally defined relationships I describe above.

These theories suggest a more nuanced argument than Chanock's stress on the solely political imperatives of colonial state power in constraining the full assimilation of customary law by the common law by imposing an artificial divide between them (Chanock 1991, 62-73). Chanock argues that as Africans increasingly took up wage labour, they became integrated into a single economy governed by laws and principles of contract. According to this view, customary law was the "residue" left when the more substantial concerns of colonial governance, such as crime, labour contract and commercial credit and debt had been subsumed under common law and statute (Chanock 1991, 67; Chanock 1994, 301; Moore, 1986, 317). In reality each set was influenced and affected by the interaction of colonial and African legal concepts, in the course of which customary law was transformed. The very concept of land tenure is "a contested, shifting terrain; ... an integral part of making claims to land can involve debating the nature of tradition" (Pierce 2013, 143, cf Chanock 1991, 63). Legal pluralism is, as Peters puts it, "a contradictory blend and not a neat parallel" (Peters 2006, 86).

\section{Change and continuity in the management and devolution of lineage land}

The discussion above attempts to contextualise the contests over the meaning of property and its inheritance, exemplified by the tension between individual autonomy and participation in social networks. We have seen how various norms and mechanisms, such as custodianship and attachment to the descent group ideology, override individual autonomy over property, and constrain the possibility of individual inheritance of land. Custodians are, moreover, expected to possess certain personal qualities to manage the land, such as responsibility, sobriety, capacity and dependability conceptualised as thembekileyo (trustworthiness). ${ }^{25}$ 
With the emphasis on personal attributes rather than birth, women are able to step into the role of custodianship without fundamentally altering the concept of family property. The idea that a responsible person should have personal attributes clashes fundamentally with the idea of formal inheritance of the property through the pre-selection of an appointed heir or heirs with powers of alienation. Such attributes cannot be predicated on wills; nor can division of material property substitute for the role of a caretaker and property manager (Kingwill 2014a, 218-221).

It is therefore the older concept of indlunkulu, head of the family, that appears to have yielded to a concept of custodianship, rather than the concept of the Xhosa heir, or indlalifa. The former refers to the person responsible for the welfare of the collective household(s). The concept of an heir, on the other hand, historically involved the inheritance and distribution of moveable property, usually cattle. While these two concepts could be fused in one person, title holders these days are at pains to avoid invoking indlalifa (heir) with respect to the family land. (Kingwill 2014a, 212-214)

It follows that if individuals do not have powers to own or dispose of the property, there can be no inheritance by individuals. The property passes to successive generations by dint of social affiliation. Colonial officialdom misinterpreted African succession norms regarding land, forcing a fit with male primogeniture. Thus customary positions of authority and the control of transmission of moveable property (principally cattle), both of which were predicated on birth, were erroneously extended to inheritance of land. ${ }^{26}$ In so far as there was an African customary concept of male primogeniture, it was succession to a position of authority and not to land (Bhe minority judgement: para 5; Mbatha 2002). The freeholders themselves almost universally reject the term indlalifa (heir) in relation to immovable property. Primogeniture matches neither the non-proprietary prescripts of African freehold nor the concept of custodianship. ${ }^{27}$

These ambiguities in terminology are also reflected in the gaps between law and practice. As already discussed, laws governing property and succession in most African countries do not capture the patterns so far described, but instead force a choice between either individualised rights or colonial versions of customary rights. The former comprise registered rights defined by the formal cadastre, with one-on-one property relationships, which, for purposes of transmission, are correlated with a Eurocentric family form. Official customary succession law, on the other hand, characterises anachronistic notions of custom that were reconstructed or "invented" during the colonial era, and which elevate male powers over land. I have argued that the practice of validation of claims to land follows neither of these two scenarios above. Living customary practices recognise the claims of both male and female kin to family property, albeit with unequal powers of control.

As alluded to above, the invented law of succession during the colonial era confused concepts of customary succession to positions of authority with succession to material 
objects, such as property rights in land (see Bhe minority judgement). The new rules were backed by male elders threatened by the prospect of women achieving independent proprietary powers as wives (Chanock 1994, 319, 2001, 277-282). These distorted "customary" rules of succession damaged the legitimate customary claims of female kin to their rights of access and succession to the family property.

Women, in particular, struggle to navigate a path through this mire of contradictory pressures. The concept of family property generates tensions between the interests of the lineage as a whole and interests of individual members of the family, particularly wives. Lineage interests often trump conjugal interests in the contexts discussed in this article. While sisters' rights of access are associated with their agnatic ties to the family, women who marry into a property owning patrilineage encounter circumscribed rights to control this property. Moreover, they relinquish rights to their own lineage land on marriage, but this does not permanently extinguish their claims as sisters/daughters. They may assert or reassert their rights of access as single, separated or divorced women. Their claims are strengthened if they retain or re-adopt the family name, since this confirms their disaffiliation from their affinal (relatives by marriage) social ties in order to reassert claims to family land. These mechanisms diminish the threat of family property passing out of the domain of the landowning lineage into the hands of affines.

The significance of marriage for rights in immovable property in the modern world represents a profound point of disjuncture between western-style and customary legal frameworks. Families that reckon genealogies through the male or female line follow different sets of assumptions, and come to different conclusions, regarding the distribution of rights in landed property than families that reckon relationships according to the centrality of the conjugal couple. It is hardly surprising that greater numbers of married women are contesting the unequal terms of property distribution; but more significant still is the evidence of increasing numbers of women who are rejecting marriage (Claassens and Mnisi 2009).

It may be stretching the argument too far to suggest that women's status as unmarried women carries a greater chance of legitimacy for recognition of property rights in land than their status as married women, but the outcome cannot be dismissed entirely. Evidence that single women are demanding and acquiring plots of land in their own right in "communal" areas (Claassens and Mnisi 2009; Cousins 2013) would support such an argument if one thinks of these claims in terms of the succession rights of daughters and sisters, i.e. unmarried or divorced female members of the family who cannot be accommodated on large family plots, such as those of the freeholders in the case studies described above. Under circumstances of forced villagisation, congestion and shrinking plots, segments of the family unit cannot be accommodated on family plots. The increasing incidence of single women acquiring their own plots of land should not therefore be regarded as a signal of a radical shift from customary normative patterns of family life, but should rather be seen as extension and adaptation thereof, following Moore's conceptualisation of "situational adjustment" (Moore 1978). Women's recourse to constitutional values of gender equity in arguing for land 
rights (see Claassens and Mnisi 2009) provides an important source of formal, legal support for their claims, but does not in itself imply a complete change in direction.

What does this mean for the Mmusi case? We have characterised women's rights to immovable property in contexts where descent ideologies continue to have some resonance. In such situations, the rights of the sibling group trump the ties of husband and wife, or the conjugal unit, when it comes to access rights to family land. The resilience of Edith Mmusi and her sisters' pursuit of justice through the courts provides an exemplary case of the strength of such claims, although, surprisingly, they did not articulate their claims in these terms. The legal discourse was mediated through the lens of the malefemale binary, which meant that the relative rights of sisters/daughters over wives were never made explicit.

Edith Mmusi's own ambiguous status as "married woman" bearing her late husband's name rather than the family name, Ramantele, may have weakened the merits of her and her sisters' claims to the family property, and bolstered the claims of their nephew. ${ }^{28}$ The important shift in the living practices of custom in the cases discussed above indicates a strong preference towards sisters'/daughters' succession to property over the claims of collateral male kinsmen (Kingwill 2014a, 199-200, 232-246, 273). This trend is an example of "situational adjustment" and "regularisation" (Moore 1978). The customary repertoire is not abandoned, but the circle of eligible kin is narrowing in response to the claims of female kin.

Mmusi occupied the position of custodian previously reserved for men, which also provides a means by which women strengthen their powers of control of family property. As discussed in the cases above, a "responsible person", or custodian, both manages the property and protects the integrity of the family (including taking care of the indigent). Custodians play a dual role in cementing the link between the property and the kin group as a whole, and protecting the property against alienation. There is much evidence in the case material discussed above, and the Mmusi case, that a significant shift is taking place from the obligatory appointment to the position of custodian of a token male head of household to the most capable person, frequently senior female agnates. In the urban case discussed above, Fingo Village, female custodians are often preferred due to the perceived "irresponsibility" of men in the family who attempt, and in some cases succeed, in selling off the family property without the consent of the family as a whole, leading to longlasting disputes. In other words, there is a shift from heritable and ascribed roles to "achieved" roles based on personal attributes (Kingwill 2014a, 46, 64, 339; Berry 1989b, 42, Berry 1993, 166).

Mbatha (2002, 260) explains the historical principles underlying custodianship, which are linked to the control functions of property: 
The original purpose underlying the customary law of succession was to protect the family and the community as a whole from the burden of looking after the deceased's dependants. Customary succession rules sought to achieve this goal by entrusting the responsibility of seeing to the welfare of the deceased' dependants to one person, in return for the right to control family property.

Other important factors influencing claims are economic considerations. In the Mmusi case, the property's proximity to an urban centre means it could generate an important source of income from tenants. Attempts to appropriate control over the rents from tenancy on family property are a significant source of tension, as are attempts to pocket the proceeds of sale of the family property. These conflicts trigger reinterpretations and new uses of "custom" by the various disputing parties (see cases in Kingwill 2014a, 179180, 206-7, 236-9).

In South Africa, the Constitutional Court judgement in the trilogy of cases known collectively as the Bhe judgement revolved around cases where official customary law was challenged when collateral kinsmen attempted to inherit property claimed respectively by the female children of the deceased, and the sister of the deceased. The judgement struck down the provision of male primogeniture in official customary law as unconstitutional, correctly so. The judgement did not, however, come to grips with the differential layers of rights and powers in families, nor the importance of reckoning relationships by descent, concluding that all women are uniformly disadvantaged. Failing the active development of the customary law of succession by the legislature in line with the constitution, the judgement had the effect of obliterating the customary law of succession. All that currently remains is the common law that calculates affiliation according to conjugality. Although the judgement has come to represent something of a moral compass for women's land rights, the judgement stopped short of providing a durable and constructive solution.

\section{Conclusion}

In my response to the Mmusi article I draw attention to distinctive processes that differentiate the passage of property in predominantly African-oriented value systems from the individual inheritance of land in western-law oriented systems of land ownership and transmission. I do this by providing some insight into social relationships that animate land holding ideology and practice, which in turn shape the devolution of land, in two research sites in the Eastern Cape.

I conclude that the various social devices that the landowners employ to hold "family land" as a social asset in the family are inadequately understood in official circles and are not accommodated in any formal legal principles. The normative bases of these organising principles are thus not embodied in any corpus of law, be it the common law or customary law.

The respective prisms used in the Mmusi article, and this response to it, recall the analytical framework suggested by Von Benda-Beckmann, von Benda-Beckmann and 
Wiber (2006, 14-25) that distinguishes between the legal-institutional realm and the realm of lived experience and practice. The former involves socio-legal and institutional abstractions and principles employed in legal discourses, arenas and texts, both in state law and non-state law ("normative orders"). The latter, which involves living practice, concerns the concrete expressions of property relationships in day-to-day social relationships. The authors label these as the "categorical" and "concretised" domains respectively.

The legal-institutional layer is defined as... a legitimising and an organisational blueprint for property relationships, as well as the procedural and substantive repertoire to clarify problematic issues, notably disputes. Legal-institutional categories spell out the rules and procedures for the appropriation and transfer of rights [...] and include the normative expression of property rights (von Benda-Beckmann, von Benda-Beckmann, and Wiber, 2006, 16).

The concretised realm, on other hand, is "the layer of actual social relationships... between property-holders with respect to concrete valuables", which are often expressed in relation to wider social networks where "property relations form one important component of multiplex relationships" Property relationships are embedded in broader social relations, and property interactions maintain, change or create new social relationships, which are in turn shaped by the outcomes of wider interactions (2006, 19-20; 25-26).

These two realms are thus integrally related. Though production practices and social relationships are shaped by principles and rules of property law, they are not, however, the same as those principles and rules. There is theoretical utility in differentiating between them, as "they are different social phenomena and constitute different constraining and enabling elements for social interaction" $(2006,25)$. The two levels thus require distinctive discursive and analytic lenses to avoid conflating one with the other.

The Mmusi article emphasises legal discourses and institutions such as the courts and processes that influence the interpretation of law and the development of jurisprudence under conditions of legal pluralism. The focus of analysis is on law, largely concerned with the relationships of power that inflect the outcomes of court cases - in this case concerning inheritance of land - both in terms of whose voices are heard and how knowledge is constructed and interpreted in courts. My response interrogates the "concretised" realm, looking at examples of change and continuity in actually-existing social relationships reflected through the lenses of particular case studies, and raising problems for interpretation and analysis of social norms under conditions of legal pluralism.

It is, however, not possible to develop these arguments in silos. The normative repertoire arising from the cases studies itself represents a "categorical" layer, but one that is not 
aligned with state law and indeed is mostly in tension with state law. By abstracting freeholders' normative principles from the messy jumble of day-to-day social relationships, it is possible to make sense of the divergences between their social tenure practices and the rules of state law. The freeholders' reticence to officially register transfers, by way of example, is a rational response to prevent individual appropriation of family property. From the state bureaucracy's point of view, however, this practice is considered illegal, usually attributed to ignorance of the law, or poverty, a phenomenon that must be remedied. It is thus clear that the layer of legal abstraction and the layer of social relationships cannot be examined in isolation of each other. Each shapes the other.

The study of African freeholders' normative repertoire, which explicates the rationale behind their property relationships, is a good example of what Moore conceptualised as a "semi-autonomous social field" (Moore 1973), a layer of social organisation and mutually interactive relationships that are neither fully congruent with, nor completely disconnected from, state law and central institutions.

The empirical findings help to shed light on numerous problematic phenomena that result from poor cross-cultural translation of property concepts (Pierce 2013, 156-7), such as faulty land titling policies, non-maintenance of land registers and the failure to satisfactorily connect ownership and inheritance. The cultural significance of the composition of the family unit for the purposes of the distribution of property is central to all these problems. The findings show how rights to familial land, whether or not it is parcelled under title, remain subject to social controls of various orders that are influenced by the social organisation of family life. Family members make claims to family property based on socially sanctioned mechanisms derived from social identity, frequently related to descent group ideology, which means that the qualifying criteria to rights in the family property differ from those that are sanctioned in the law. State sanctions such as title and official succession rules thus play an insignificant role in how land is transmitted.

Legal interpretations have consequences for how women's rights to land are conceptualised. Women's lack of access to powers of "control" of land tends to be conflated with a generalised lack of access to land rights per se. The reality is far more complex, and a great many factors combine with the gendered structuring of familial relationships that result in a unique conception of family property that is cut across by tensions of various kinds. In addition to tensions that arise from the power differentials of gender, are tensions generated by the respective claims of kin and non-kin. The principles that underpin legitimate claims do not impact equally on the rights of all women.

Women have found, and are finding, spaces in the interstices of customary normative orders to claim rights as they increasingly and successfully invoke the powers of female succession in terms of agnatic or enatic relationships. These, however, have implications for the future status of marriage and conjugality. More and more research findings are pointing to the downturn in African marriages (Claassens \& Mnisi 2009, 2012; Claassens 
2013). It would certainly seem that the most profound tensions are generated for women as wives (Kingwill 2014a, 71).

The argument for "living law", which played an important corrective role in the Mmusi judgement, has gained much currency in post-colonial contexts on account of the wide and widening gap between official sources of law and social norms and practices. I argue that the concept of living law does not adequately reflect the complicated social channels along which property contests move. The result is that analyses tend to over-simplify the nature of gendered struggles over property, and women's property rights tend to be conflated with western-style individual rights, since these are more easily translatable into a "rights" discourse (cf. Nhlapo 2000; Whitehead and Tsikata 2003). While the "living law" discourse helps to make local struggles more visible, it does not tend to capture the asymmetric power involved, such as between "insiders" and "outsiders"; kin and non-kin; affinal versus consanguine relationships; daughters and wives; youth and powerful elders; or marginalised groups and central institutions, and so forth.

Although the Constitutional Court in South Africa has in many cases accepted the idea and implications of living law rather than outdated official law, many of the constitutional court judgements have failed to go far enough in advancing the ideal of parity between the common law and customary law, and indeed in practice may be contributing to the overshadowing of customary norms by imprinting western value systems on them. There is more to the dynamic of social change than a simple switch from customary to common law values. Perhaps the greater responsiveness of the common law to social change accounts for jurists' tendency to fall back on common law norms when customary law appears to be unyielding.

Highly significantly, the final judgement in the Mmusi case did not find that the customary law of succession is inherently discriminatory, which was implied in a previous lower court judgement, but accepted that customary law is flexible and can allow for female inheritance. The judgement did not therefore imply that living law means adopting a new set of values. On the contrary, the judgement respected the ability of customary law to accommodate the interests of women without the implication that it had to change fundamentally. In this respect, I argue, the Mmusi judgement departs from the South African Constitutional Court case, the Bhe judgement, which could be seen as striking a blow at the customary law of succession in South Africa, though not in an unqualified manner.

The long-term impact of aligning law with custom could contribute to the ultimate integration of the common law and customary law into a single common law system for South Africans, one that respects and tolerates diverse cultural manifestations of family life, among many other indices.

I argue that the term "inheritance" should be problematised to take into account situations where land is not individually owned and inherited. For inheritance is not a 
free-standing concept, over which people have particular agency, but is a site of struggle and contestation. Inheritance is always about social relations, and in most cases about how people understand their relatedness to others, in particular their kin. In other words, how, culturally, people define their social identities. It is never culture-neutral whether we speak of African or Eurocentric notions of property and its transmission. A key distinction emerges globally between the relative importance that is attributed to the conjugally defined family or the descent-based family for purposes of succession.

The important point about inheritance is that it always implies exclusion. Whoever inherits (whether male or female, son or daughter, wife or husband) will always be excluding others from inheriting. Ironically, the access rights of vulnerable members of the family (often women and children) may thus be adversely affected by the trend towards individualisation of inheritance, whether by women or men.

Behind the labels of "living law" and "law as process", which the author of the Mmusi article used as her prism, are social relational issues that shape, and are shaped by, gender relations and complicated dynamics of power that condition the control of knowledge and the construction of law. These are the issues that are actually being contested, and the "arena" of contestation (the courts) is a means by which the actors (the litigants, lawyers and the state) liberate, suppress, interpret, balance, defend and manipulate their understanding of these relationships which are changing, sometimes without the full awareness of the actors.

\section{Notes}

1. Pauline Peters, email to the author, 29 November 2015.

2. The unit involved has been renamed the Land and Accountability Research Centre (LARC).

3. The corporate structure of lineages exemplified by Fortes' (1953) study is exaggerated. As Befu \& Plotnicov $(1962,314)$ point out, the common features lineages share with corporations, such as: "a corporation is composed of a plurality of individuals; the life of the corporation is independent of its individual members; and, membership is limited to individuals of certain qualification" are not peculiar to corporations but are shared by other types of social groups.

4. The Native Administration Act, No 38 of 1927 s 8 made provision for administrative shortcuts to effect registration. The Act provided for the appointment of titles commissioners with powers of adjudication and conveyancing, reproduced in more recent legislation, the Land Titles Adjustment Act, No. of 111, 1993.

5. Interview with Seth Ndawo (pseudonym), Rabula, 1 April 2008.

6. A title commissioner appointed in terms of the Land Titles Adjustment Act, No 111 of 1993.

7. Interview with Seth Ndawo (pseudonym), Rabula, 1 April 2008.

8. Interview with Bongani Makuzeni, Rabula, 14 July 2006.

9. Interview with Mandla Makuzeni, Rabula, 15 May 2008.

10. Interview with Linda Sindiso Mnyemeni, Fingo Village, 9 June 2006. 
11.Interview with Siphiwo Baninzi, Fingo Village, 9 March 2010.

12. E.g. the Removal or Modification of Restrictions on Immovable Property Act of 1916 provided for testamentary dispositions and discouraged family entitlements.

13. South African property law allows for 'undivided shares' but these are expressed in mathematically calculated percentages of the whole.

14. Agnatic relationships are calculated through the male line of descent and apply to all children, male and female, who are associated with the lineage of the original founding father. Wives have a different status from daughters, who have legitimate claims to property. See Preston-Whyte 1937, 178-204, for the anthropological analysis of agnatic relationships historically.

15. Interview, Seth Ndawo, Rabula, 1 April 2008.

16. Deduced from evidence in a number of interviews; and see Hunter, 1979, 113.

17. The ties that bind individuals to their patrilineal kin rather than their parents jointly should not be interpreted to mean an absence of affection or solidarity between nonlineal mothers or fathers. It was not irregular to omit the matter of the children's paternity in the cases discussed, since this was not relevant to the rights of the children to the family property symbolised by the family name. No obvious conclusions regarding their relationship with their father can be drawn from this.

18. Though not conceptualised quite in this way, these conclusions were confirmed in interviews about the roles of family members. Interview, M. Jara, Grahamstown, 14 October 2011 and N. Gysman, Grahamstown, 29 August, 2013.

19. The family also disputed her status as wife. The oral information was acquired during five interviews in Fingo Village: with Nomtunsi Maureen Radebe at No. 2 Albert Street on 14 January 2008 and 16 March 2010; and five relatives at No 14 Victoria Street on 24 March 2010, 8 September 2010 and 22 September 2010 (pseudonyms of names and streets). Title deed information from Deeds Registry, Cape Town.

20.In terms of section 23 of the Native Administration Act, No 38 of 1927. $C f$ minority judgement in Bhe \& Others $v$ Magistrate Khayelitsha \& Others 2005 (1) SA 580 (CC), 2005 (1) BCLR 1. The law established an order called the 'Tables of Succession' whereby land was inherited by a man's senior son and then in turn passed to his senior son, and so on. Failing direct male heirs, it passed to collateral male kinsmen, i.e. brothers or uncles, to keep succession in line with male-to-male succession.

21. Bhe \& Others $v$ Magistrate Khayelitsha \& Others 2005 (1) SA 580 (CC), 2005 (1) BCLR 1. The judgement resulted in the application of the common law of succession to apply to all South Africans (unless the legislature develops the customary law of succession, which it has not), which occasioned an amendment to the Intestate Succession Act, No 81 of 1987.

22. In terms of the amended Intestate Succession Act, No 81 of 1987.

23. I am indebted to Leslie Downie for having thought of this term to describe normative patterns.

24. Compare Okoth-Ogendo's correspondence of power and property with Ribot and Peluso's $(2003,153)$ distinction between the "ability to derive benefit from things" and the "right to benefit from things' which they conceptualise in terms of the 
distinction between "a bundle of powers" (that define ability to benefit from access) and property's notion of a "bundle of rights." They argue that "[t]his formulation includes a wider range of social relationships that constrain or enable benefits from resource use than property relations alone".

25. From ukuthembeka (to trust). The expression means a person who has proved to be trustworthy.

26. See $\mathrm{n} 20$ above. The Tables of Succession were invented by colonial officialdom in terms of section 23 of the Native Administration Act of 1927 to legalise a form of collateral succession through horizontal links along the male line, precluding women.

27. Interview, Siphiwo Baninzi, Fingo Village, 9 March 2010; Seth Ndawo, Rabula, 1 April 2008.

28.It would be illuminating to know whether, in challenging the claims of their nephew Molefi Ramantele, Edith Mmusi and her siblings' case would have been strengthened had they reverted from their married names to their family name, Ramantele, assuming this is legally possible in Botswana.

\section{Acknowledgements}

My grateful thanks go to Tara Weinberg for engaging with me on her Mmusi article published in this issue, and for graciously allowing me to respond; and Aninka Claassens, Director of the Land and Accountability Research Centre, Faculty of Law, University of Cape Town, for encouraging the publication of both of our articles.

\section{Disclosure statement}

No potential conflict of interest was reported by the author. 


\section{References}

Befu, Harumi, and Leonard Plotnicov. 1962. "Types of Unilineal Descent Groups." American Ethnologist 64: 313-327.

Berge, E., D. Kambewa, A. Munthali, and H. Wiig. 2014. "Lineage and Land Reforms in Malawi: Do matrilineal and Patrilineal Landholding Systems Represent a Problem for Land Reforms in Malawi?” Land Use Policy 41: 61-69.

Berry, Sara. 1989a. "Access, Control and use of Resources in African Agriculture: An Introduction." Africa Journal of the International African Institute 59 (1): 1-5.

Berry, Sara. 1989b. "Social Institutions and Access to Resources." Africa Journal of the International African Institute 59 (1): 41-55.

Berry, Sara. 1993. No Condition is Permanent: The Social Dynamics of Agrarian Change in Sub-Saharan Africa. Madison: University of Wisconsin Press.

Bohannan, Paul. 1963. "Land', 'Tenure' and Land-Tenure'." In African Agrarian Systems, edited by Daniel Biebuyck, 101-115. London: Oxford University Press for International African Institute.

Chanock, Martin. 1991. "Paradigms, Policies and Property: A Review of the Customary Law of Land Tenure." In Law in Colonial Africa, edited by Kristin Mann and Richard Roberts, 61-84. Portsmouth: Heinemann \& James Currey.

Chanock, Martin. 1994. "The South African Native Administration Act of 1927: Reflections on a Pathological Case of Legal Pluralism." In The Rights of Subordinated Peoples, edited by Oliver Mendelsohn and Upendra Baxi, 295-323. Delhi: Oxford University Press.

Chanock, Martin. 2001. The Making of South African Legal Culture 1902-1936. Cambridge: Cambridge University Press.

Claassens, Aninka. 2013. "Recent Changes in Women's Land Rights and Contested Customary Law in South Africa." Journal of Agrarian Change 13 (1): 71-92.

Claassens, Aninka, and Sindiso Mnisi. 2009. "Rural Women Redefining Land Rights in the Context of Living Customary Law." South African Journal of Human Rights 25: 491516.

Claassens, Aninka, and Sindiso Mnisi. 2012. "Tensions Between Vernacular Values That Prioritise Basic Needs and State Versions of Customary Law That Contradict Them." In Law and Poverty: Perspectives from South Africa and Beyond, edited by Sandra Liebenberg and Geo Quinot, 381-402. Cape Town: Juta.

Colin, Jean-Phillip, and Philip Woodhouse. 2010. "Introduction: Interpreting Land Markets in Africa." Africa. Journal of the International African Institute 80 (1): 1-13.

Cousins, Ben. 2008. "Characterising 'Communal' Tenure: Nested Systems and Flexible Boundaries." In Land, Power and Custom: Controversies Generated by South Africa's Communal Land Rights Act, edited by Aninka Claassens, and Ben Cousins, 109137. Cape Town: University of Cape Town Press with the Legal Resources Centre.

Cousins, Ben, 2013. "Women's Land Rights and Social Change in Rural South Africa: The Case of Msinga, Kwazulu-Natal." Acta Juridica No. 13 (special issue on 'Marriage, Land and Custom'): 73-99.

Fortes, Meyer. 1953. "The Structure of Unilineal Descent Groups." American Anthropologist, 55 (1): $17-41$. 
Hammond-Tooke, W. David. 1984. "In Search of the Lineage: The Cape Nguni Case." Man, New Series 19 (1): 77-93.

Hunter, Monica. 1979. Reaction to Conquest: Effects of Contact with Europeans on the Pondo of South Africa. Abridged paperback ed. Cape Town: David Philip in association with Rex Collings.

Kingwill, Rosalie. 2008. "Custom-Building Freehold Title: The Impact of Family Values on Historical Ownership in the Eastern Cape." In Land, Power and Custom. Controversies Generated by South Africa's Communal Land Rights Act, edited by Aninka Claassens and Ben Cousins, 184-208. Cape Town: University of Cape Town Press with Legal Resources Centre.

Kingwill, Rosalie. 2014a. "The Map is Not the Territory. Law and Custom in "African freehold', a South African Case Study.” PhD diss., University of the Western Cape.

Kingwill, Rosalie. 2014b. "Papering over the Cracks: An Ethnography of Land Title in the Eastern Cape." Kronos: A Journal of Southern Africa 40 (1): 241-268.

Lund, Christian. 2002. "Negotiating Property Institutions: On the Symbiosis of Property and Authority in Africa." In Negotiating Property in Africa, edited by Kristine Juul and Christian Lund, 11-44. Portsmouth: Heinemann.

Mbatha, Likhapha. 2002. "Reforming the Customary Law of Succession." South African Journal on Human Rights 18: 259-286.

Mills, Elton M. and Monica Wilson. 1952. Keiskammahoek Rural Survey v 4: Land Tenure. Pietermaritzburg: Shuter and Shooter.

Moore, Sally Falk. 1973. "Law and Social Change: the Semi-Autonomous Social Field as an Appropriate Subject of Study." Law and Society Review 7 (4), 719-746.

Moore, Sally Falk. 1978. Law as Process: An Anthropological Approach (2000 ed., reprinted with International African Institute). Oxford: James Currey.

Moore, Sally Falk. 1986. Social Facts and Fabrications. "Customary" Law on Kilimanjaro, 1880-bridge: Cambridge University Press.

Moore, Sally Falk. 1987. "Explaining the Present: Theoretical Dilemmas in Processual Ethnography." American Ethnologist 14 (4): 727-736.

Nhlapo, Thandabantu. 2000. "The African Customary Law of Marriage and the Rights Conundrum." In Beyond Rights Talk and Culture Talk, edited by Mahmood Mamdani, 142-143. Cape Town: David Philip.

Okoth-Ogendo, Hastings. 1989. "Some Issues of Theory in the Study of Tenure Relations in African Agriculture." Africa Journal of the International African Institute 59 (1): 6-12.

Okoth-Ogendo, Hastings. 2008. "The Nature of Land Rights Under Indigenous Law in Africa." In Land, Power and Custom: Controversies Generated by South Africa's Communal Land Rights Act, edited by Aninka Claassens and Ben Cousins, 95-108. Cape Town: University of Cape Town Press with the Legal Resources Centre.

Peters, Pauline. 1997. "Introduction: Revisiting the Puzzle of Matriliny in South-Central Africa." Critique of Anthropology 17 (2): 125-146.

Peters, Pauline. 2002. "The Limits of Negotiability: Security, Equity and Class Formation in Africa's land systems." In Negotiating Property in Africa, edited by Kristine Juul, and Christian Lund, 45-66. Portsmouth: Heinemann. 
Peters, Pauline. 2006. "Beyond Embeddedness: A Challenge Raised by a Comparison of the Struggles Over Land in African and Post-Socialist Countries." In Changing Properties of Property, edited by Franz von Benda-Beckmann, Keebet von Benda-Beckmann, and Melanie Wiber, 84-105. New York, NY: Berghahn Books.

Pierce, Steven. 2013. "Pointing to Property: Colonialism and Knowledge About Land Tenure in Northern Nigeria." Africa: Journal of the International African Institute 83 (1): 142-163.

Preston-Whyte, Eleanor. 1937. “Kinship and Marriage.” In The Bantu-Speaking Peoples of Southern Africa, edited by W. David Hammond-Tooke, 177-210. London: Routledge \& Kegan Paul.

Rautenbach, Christa 2008. "South African Common and Customary Law of Intestate Succession: A question of Harmonisation, Integration or Abolition." Electronic Journal of Comparative Law 12 (1): 7.

Ribot, Jesse, and Nancy Peluso. 2003. "A Theory of Access." Rural Sociology 68 (2): 153-181. Roitman, Janet. 2005. Fiscal Disobedience: An Anthropology of Economic Regulation in Central Africa. Princeton, NJ: Princeton University Press.

Rutsch Howard Consortium. 2004. The Extra-Legal Land Market: Extra-Legal Land Markets in Kwazulu-Natal. Durban: KwaZulu-Natal Provincial Planning and Development Commission.

Van der Walt, Andre J. 1999. "Property Rights and Hierarchies of Power: A Critical Evaluation of Land-Reform Policy in South Africa." Koers 64 (2 \& 3): 259-295.

Van der Walt, Andre J., and Duard Kleyn. 1989. "Duplex Dominium: The History and Significance of the Concept of Divided Ownership." In Essays in the History of Law, edited by Daniel Visser, 213-260. Cape Town: Juta.

Von Benda-Beckmann, Franz, Keebet von Benda-Beckmann, and Melanie Wiber. 2006. "The Properties of Property." In Changing Properties of Property, edited by Franz von Benda-Beckmann, Keebet von Benda-Beckmann and Melanie Wiber, 1-39. New York, NY: Berghahn Books.

Weinberg, Tara. 2016. "Pushing the Boundaries of Customary Law Jurisprudence in Botswana: Social Science and the Law in the Case of Ramantele vs. Mmusi." The Journal of Legal Pluralism and Unofficial Law. doi: http://dx.doi.org/10.1080/07329113.2016.1169056

Whitehead, Anne, and Dzodzi Tsikata. 2003. "Policy Discourses on Women's Land Rights in Sub-Saharan Africa: The Implications of the Re-turn to the Customary." Journal of Agrarian Change 3 (1 \& 2): 67-112.

\section{Case Law}

Ramantele $v$ Mmusi and Others (CACGB-104-12) [2013] BWCA 1 (3 September 2013). Bhe \& Others $v$ Magistrate Khayelitsha \& Others 2005 (1) SA 580 (CC), 2005 (1) BCLR 1. 